\title{
Synthesis and catalytic properties of iron - cerium phosphates with surfactant
}

\section{(Síntese e propriedades catalíticas de ferro-fosfato de cério com surfactante)}

\author{
H. Onoda, T. Sakumura \\ Department of Informatics and Environmental Sciences, Faculty of Life and Environmental Sciences, Kyoto \\ Prefectural University, 1-5, Shimogamo Nakaragi-cho, Sakyo-ku, Kyoto 606-8522, Japan \\ onoda@kpu.ac.jp
}

\begin{abstract}
Iron phosphate was prepared from iron nitrate and phosphoric acid with a surfactant, pentaethylene glycol mono dodecyl ether. The chemical composition of the obtained samples was estimated from ICP and XRD measurements. Particle shape and size distribution were observed by SEM images and laser diffraction / scattering methods. Further, the catalytic activity was studied with the decomposition of the complex between formaldehyde, ammonium acetate, and acetylacetone. The peaks of $\mathrm{FePO}_{4}$ were observed in XRD patterns of samples prepared in $\mathrm{Fe} / \mathrm{Ce}=10 / 0$ and then heated at $600{ }^{\circ} \mathrm{C}$. Other samples were amorphous in XRD patterns. Iron-cerium phosphates had high catalytic activity for the decomposition of the complex.
\end{abstract}

Keywords: iron phosphate, cerium substitution, surfactant, ICP analysis, catalytic property.

\section{Resumo}

Fosfato de ferro foi preparado a partir do nitrato de ferro e ácido fosfórico com um surfactante éter monododecil pentaetileno glicol. A composição química das amostras obtidas foi estimada a partir de medidas por ICP e DRX. A distribuição e forma das partículas foram observadas por imagens de MEV e o pelo método de espalhamento de laser. A atividade catalítica foi estudada com a decomposição do complexo entre formaldeido, acetato de amônio e acetilacetona. Os picos de $\mathrm{FePO}_{4}$ foram observados nos padrões de DRX das amostras preparadas $\mathrm{Fe} / \mathrm{Ce}=10 / 0$ e então aquecidas a $600{ }^{\circ} \mathrm{C}$. Outras amostras foram de padrões de DRX amorfo. Ferro-fosfatos de cério tiveram alta atividade catalítica para a decomposição do complexo.

Palavras-chave: fosfato de ferro, substituição do cério, surfactante, análises ICP, propriedade catalítica.

\section{INTRODUCTION}

Phosphates have been used for ceramic materials, catalysts, fluorescent materials, dielectric substances, metal surface treatment, detergent, food additives, fuel cells, pigments, etc. [1-3]. In these uses, catalyst is one of important applications of phosphate materials. Vanadium phosphate works as a catalyst for oxidation of butane [4]. Nickel phosphate works for oxidation of alcohol [5]. Iron phosphate works for oxidation of methane [6]. Aluminum phosphate works for dehydration of alcohol [7]. Other phosphates, zirconium, cobalt, potassium phosphates, and so on, are also important as a catalyst [8-10].

Transition metal phosphates sometimes have the different ratio of cation / phosphorus with the theoretical ratio of chemical composition, because of hydrogen cation, hydroxide anion, and so on. These hydrogen cation and hydroxide anion have influence on the catalytic activity of phosphate materials, because of the formation of hydrogen site on surface. These transition metal phosphates work as solid state acidic catalyst. Therefore, the synthetic process is important to control the chemical composition of phosphate materials. Generally, the additives in preparation process were used to prepare the target particle of phosphate materials [11]. The spherical and porous particles of lanthanum phosphate were obtained by the addition of urea [12]. In this work, as a surfactant (sur), pentaethylene glycol mono dodecyl ether was used to prevent the aggregation in preparation process, which was one of the common anionic surfactant. This surfactant has 10.03 in HydrophileLipophile Balance value [13].

Transition metal phosphates have a weak point to solve in acidic and basic solutions. In previous work [14], the substitution with rare earth cation inhibited the elution of phosphates. Therefore, rare earth substituted iron phosphates have a possibility to use as a catalyst in solutions.

In this work, iron - cerium phosphates were prepared form iron nitrate, ammonium cerium nitrate, and phosphoric acid with pentaethylene glycol mono dodecyl ether. The ratios of iron / cerium and phosphorus / pentaethylene glycol mono dodecyl ether (sur) were studied in this preparation. The obtained products were estimated from their particle 
shape and size distribution, and catalytic activity. The purpose in this work is to clear the influence of cerium substitution, surfactant, and heating temperature on chemical composition and catalytic activity of iron phosphates.

\section{EXPERIMENTAL PROCEDURE}

The $0.2 \mathrm{~mol} / \mathrm{L}$ of iron nitrate, $\mathrm{Fe}\left(\mathrm{NO}_{3}\right)_{3}$, solution was mixed with $0.2 \mathrm{~mol} / \mathrm{L}$ of phosphoric acid solution in the molar ratio of $\mathrm{Fe} / \mathrm{P}=1 / 1$. This ratio is settled from the chemical composition of iron orthophosphate, $\mathrm{FePO}_{4}$. Pentaethylene glycol mono dodecyl ether, $\mathrm{C}_{12} \mathrm{H}_{25} \mathrm{O}\left(\mathrm{CH}_{2} \mathrm{CH}_{2} \mathrm{O}\right)_{5} \mathrm{H}$, (sur) was added to the mixed solution in $\mathrm{P} / \mathrm{sur}=10 / 0,10 / 1$, and $10 / 2$ to prevent the aggregation of particles. Then, the mixed solution was adjusted to $\mathrm{pH} 7$ by ammonia solution. The precipitate was decantated off and dried at $60{ }^{\circ} \mathrm{C}$ in air condition. The cerium - substituted samples were also prepared to compare with iron phosphates. A part of iron nitrate was substituted with ammonium cerium nitrate, $\left(\mathrm{NH}_{4}\right)_{2} \mathrm{Ce}\left(\mathrm{NO}_{3}\right)_{6}$, in $\mathrm{Fe} / \mathrm{Ce}=8 / 2$. The four iron (+III) cations were replaced with three cerium (+IV) cation. In this work, the ratio of $\mathrm{P} /(3 \mathrm{Fe}+4 \mathrm{Ce})$ was $1 / 3$. All chemicals were of guaranteed reagents from Wako Chemical Industries Ltd. (Osaka, Japan) without further purification.

A part of the precipitates was dissolved in hydrochloric acid solution. The ratios of phosphorus, iron, and cerium in the precipitates were also calculated from Inductively Coupled Plasma (ICP) results of these solutions, using SPS1500VR, Seiko Instruments Inc. The thermal behavior of these materials was analyzed by X-ray diffraction (XRD). XRD patterns were recorded on a Rigaku Denki RINT 2000 $\mathrm{X}$-ray diffractometer using monochromated $\mathrm{Cuk} \alpha$ radiation.

The powder properties of thermal products at 60,200 , 400 , and $600{ }^{\circ} \mathrm{C}$ were characterized by particle shape and size distribution. Particle shapes were observed by scanning electron micrographs (SEM) using JGM-5510LV, Jeol Ltd. Particle size distribution was measured with laser diffraction / scattering particle size distribution Horiba LA-910.

Further, as an application of phosphates, the catalytic activity of these iron - cerium phosphates was studied with the decomposition of the following complex.

$\mathrm{HCHO} \cdot \mathrm{H}_{2} \mathrm{O}+\mathrm{CH}_{2} \mathrm{COONH}_{4}+2 \mathrm{CH}_{3} \mathrm{COCH}_{2} \mathrm{COCH}_{3} \rightarrow$<smiles>CC(=O)C1=C(C)N=C(C)C(=C(C)[O-])C1</smiles>

$$
+\mathrm{CH}_{3} \mathrm{COOH}+4 \mathrm{H}_{2} \mathrm{O}
$$

Formaldehyde was formed the complex with ammonium acetate and acetylacetone. This complex has the light adsorption at $415 \mathrm{~nm}$. Samples were added in this solution and then shaken for $24 \mathrm{~h}$. The strong catalyst decomposed this complex. Therefore, the adsorption at $415 \mathrm{~nm}$ became small. The catalytic activity of iron - cerium phosphate was estimated from this adsorption at $415 \mathrm{~nm}$.

\section{RESULTS AND DISCUSSION}

Chemical composition and powder properties of iron -cerium phosphates

All obtained samples were yellow powder in color, therefore the iron condition in precipitate is mainly trivalent state. Table I shows the chemical composition of precipitates from ICP measurements. Because the $\mathrm{Fe} / \mathrm{P}$ ratio in iron phosphate, $\mathrm{FePO}_{4}$, is 1 , samples contained a certain degree

Table I - Chemical composition of precipitates from ICP measurements.

[Tabela I - Composição química dos precipitados medidos por ICP.]

\begin{tabular}{ccccccc}
\hline & \multicolumn{3}{c}{ Preparation } & \multicolumn{4}{c}{ Precipitate, FexCeyHzPO4 } \\
& $\mathrm{Fe} / \mathrm{Ce}$ & sur/P & $\mathrm{X}$ & $\mathrm{y}$ & $\mathrm{z}$ & $\mathrm{Fe} / \mathrm{Ce}$ \\
\hline $\mathrm{A}$ & $10 / 0$ & $0 / 10$ & 0.812 & - & 0.564 & - \\
$\mathrm{B}$ & $8 / 2$ & $0 / 10$ & 0.750 & 0.125 & 0.250 & $8 / 1.33$ \\
$\mathrm{C}$ & $10 / 0$ & $1 / 10$ & 0.840 & - & 0.480 & - \\
$\mathrm{D}$ & $8 / 2$ & $1 / 10$ & 0.681 & 0.115 & 0.497 & $8 / 1.35$ \\
$\mathrm{E}$ & $10 / 0$ & $2 / 10$ & 0.868 & - & 0.396 & - \\
$\mathrm{F}$ & $8 / 2$ & $2 / 10$ & 0.686 & 0.120 & 0.462 & $8 / 1.40$ \\
\hline
\end{tabular}

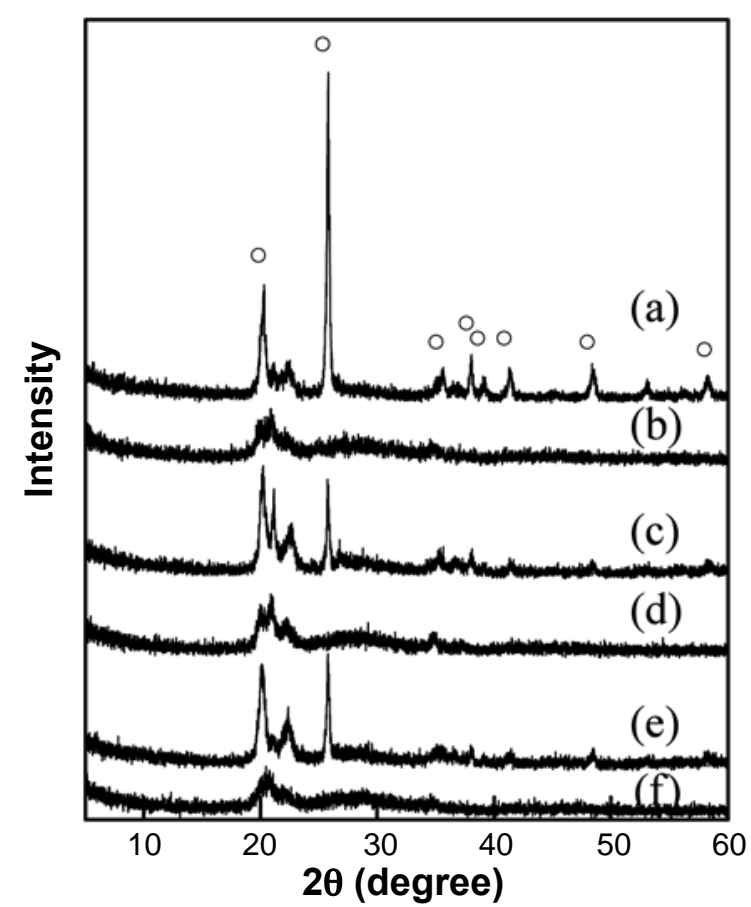

Figure 1: XRD patterns of samples heated at $600{ }^{\circ} \mathrm{C}$, (a) $\mathrm{Fe} /$ $\mathrm{Ce}=10 / 0, \mathrm{P} /$ sur $=10 / 0$, (b) $\mathrm{Fe} / \mathrm{Ce}=8 / 2, \mathrm{P} /$ sur=10/0, (c) $\mathrm{Fe} / \mathrm{Ce}=10 / 0$, $\mathrm{P} /$ sur $=10 / 1$, (d) $\mathrm{Fe} / \mathrm{Ce}=8 / 2, \mathrm{P} / \mathrm{sur}=10 / 1$, (e) $\mathrm{Fe} / \mathrm{Ce}=10 / 0, \mathrm{P} /$ sur=10/2, and (f) $\mathrm{Fe} / \mathrm{Ce}=8 / 2, \mathrm{P} / \mathrm{sur}=10 / 2, \circ ; \mathrm{FePO}_{4}$.

[Figura 1: Difratogramas de raios $X$ das amostras aquecidas a $600{ }^{\circ} \mathrm{C}$, (a) $\mathrm{Fe} / \mathrm{Ce}=10 / 0$, P/sur $=10 / 0$, (b) $\mathrm{Fe} / \mathrm{Ce}=8 / 2, \mathrm{P} / \mathrm{sur}=10 / 0$, (c) $\mathrm{Fe} / \mathrm{Ce}=10 / 0, \mathrm{P} / \mathrm{sur}=10 / 1$, (d) $\mathrm{Fe} / \mathrm{Ce}=8 / 2, \mathrm{P} / \mathrm{sur}=10 / 1$, (e) $\mathrm{Fe} /$ $\mathrm{Ce}=10 / 0, \mathrm{P} / \mathrm{sur}=10 / 2$, e (f) $\mathrm{Fe} / \mathrm{Ce}=8 / 2, \mathrm{P} / \mathrm{sur}=10 / 2$, o; $\mathrm{FePO}_{4}$.] 

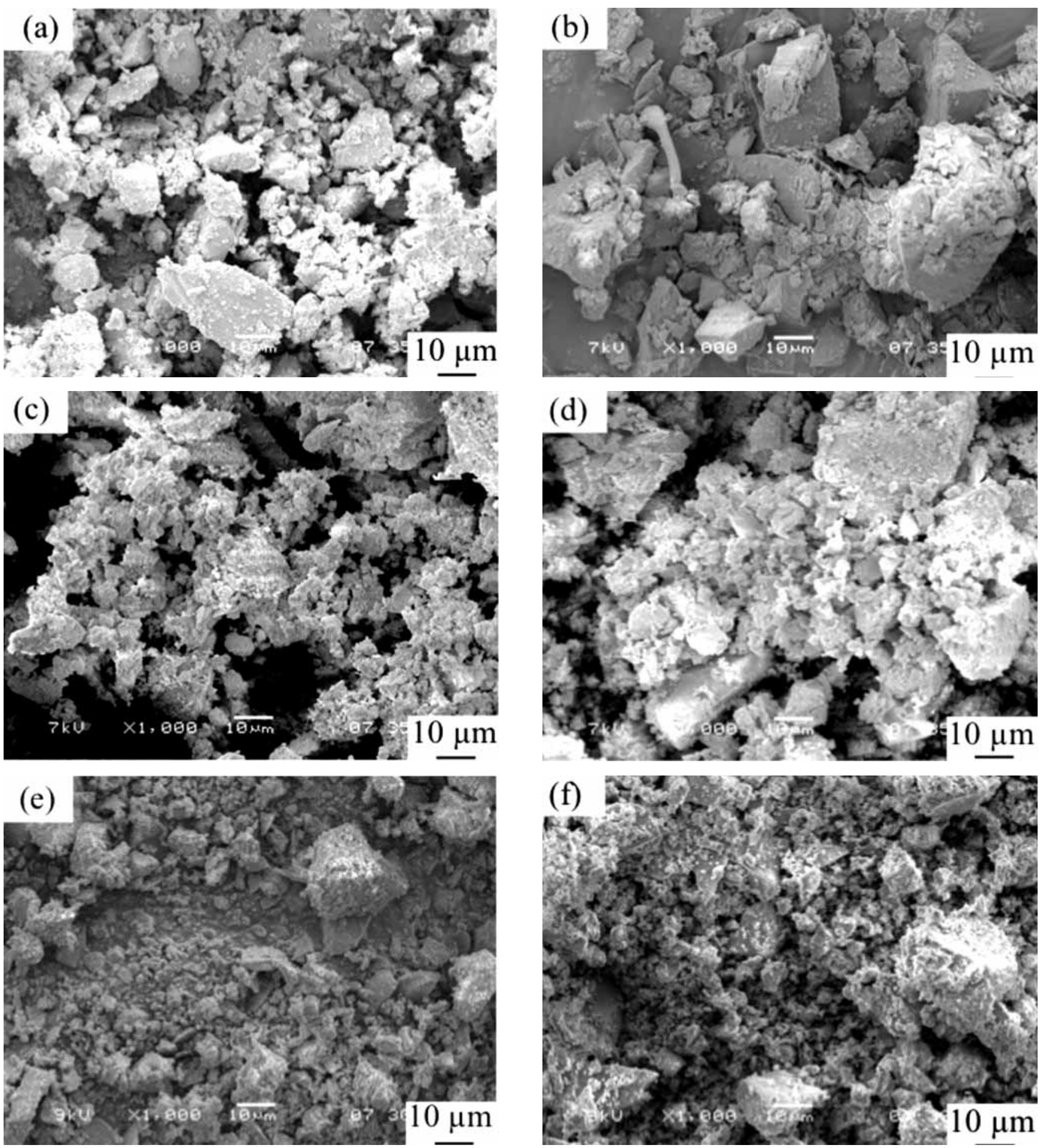

Figure 2: SEM images of samples, (a) $\mathrm{Fe} / \mathrm{Ce}=10 / 0, \mathrm{P} / \mathrm{sur}=10 / 0,60^{\circ} \mathrm{C}$, (b) $\mathrm{Fe} / \mathrm{Ce}=8 / 2, \mathrm{P} / \mathrm{sur}=10 / 0,60{ }^{\circ} \mathrm{C},(\mathrm{c}) \mathrm{Fe} / \mathrm{Ce}=10 / 0, \mathrm{P} / \mathrm{sur}=10 / 2,60{ }^{\circ} \mathrm{C}$, (d) $\mathrm{Fe} / \mathrm{Ce}=8 / 2$, P/sur=10/2, $60{ }^{\circ} \mathrm{C}$, (e) $\mathrm{Fe} / \mathrm{Ce}=10 / 0, \mathrm{P} /$ sur $=10 / 2,600^{\circ} \mathrm{C}$, and (f) $\mathrm{Fe} / \mathrm{Ce}=8 / 2, \mathrm{P} / \mathrm{sur}=10 / 2,600^{\circ} \mathrm{C}$

[Figura 2: Imagens de microscopia eletrônica de varredura das amostras (a) $\mathrm{Fe} / \mathrm{Ce}=10 / 0, \mathrm{P} / \mathrm{sur}=10 / 0,60{ }^{\circ} \mathrm{C},(\mathrm{b}) \mathrm{Fe} / \mathrm{Ce}=8 / 2, \mathrm{P} / \mathrm{sur}=10 / 0$, $60{ }^{\circ} \mathrm{C}$, (c) $\mathrm{Fe} / \mathrm{Ce}=10 / 0, \mathrm{P} / \mathrm{sur}=10 / 2,60{ }^{\circ} \mathrm{C}$, (d) $\mathrm{Fe} / \mathrm{Ce}=8 / 2, \mathrm{P} / \mathrm{sur}=10 / 2,60{ }^{\circ} \mathrm{C}$, (e) $\mathrm{Fe} / \mathrm{Ce}=10 / 0, \mathrm{P} / \mathrm{sur}=10 / 2,600{ }^{\circ} \mathrm{C}, e(f) \mathrm{Fe} / \mathrm{Ce}=8 / 2, \mathrm{P} /$ sur $\left.=10 / 2,600^{\circ} \mathrm{C}.\right]$

of proton, like $\mathrm{Fe}_{0.812} \mathrm{H}_{0.564} \mathrm{PO}_{4}$. The presence of proton is important to use as a phosphate catalyst. The cerium ratio in precipitate was lower than that of preparation condition. In previous works $[15,16]$, lanthanum ratio in precipitates was higher than that in preparation condition. This difference is considered to be form the valence state of rare earth cation. Cerium cation in this work is tetravalent one, on the other hand, lanthanum cation in previous works is trivalent one. Trivalent rare earth cation was much easy to react to phosphate materials. It is well known that trivalent rare 
earth phosphates are a main composition of Monazite ore and insoluble for acidic and basic solution in the groups of phosphate materials. The addition of pentaethylene glycol mono dodecyl ether had less influence on the $\mathrm{Fe} / \mathrm{Ce}$ ratio in precipitates.

Samples heated at 60,200 , and $400{ }^{\circ} \mathrm{C}$ had unknown small peaks in XRD patterns. A large part of these samples were amorphous state by XRD analysis. Generally, phosphate materials prepared in a solution are amorphous in XRD analysis. Amorphous phosphate materials expected to have various kinds of acidic sites to work as an acidic catalyst. Fig. 1 shows XRD patterns of samples heated at $600{ }^{\circ} \mathrm{C}$. Samples prepared in $\mathrm{Fe} / \mathrm{Ce}=10 / 0$ had peaks of $\mathrm{FePO}_{4}$ in spite of the surfactant ratio (Fig. 1a,c,e). On the other hand, samples prepared in $\mathrm{Fe} / \mathrm{Ce}=8 / 2$ were amorphous or had the small peaks in XRD patterns (Fig. $1 \mathrm{~b}, \mathrm{~d}, \mathrm{f})$.

Fig. 2 shows SEM images of samples prepared in various conditions. No specified shapes were observed in this work. By the substitution with cerium cation, large particles formed (Fig. 2a,b). The addition of surfactant made the particle size of phosphates smaller (Fig. 2c,d). The heating temperature had no influence on particle shape of iron-cerium phosphates (Fig. 2e,f,). Fig. 3 shows the particle size distribution of samples prepared in $\mathrm{Fe} / \mathrm{Ce}=10 / 0$ and $8 / 2$. The particle size of iron - cerium phosphates were from 2 to $500 \mu \mathrm{m}$. The $\mathrm{Fe} / \mathrm{Ce}$ ratio and $\mathrm{P} /$ sur ratio had small changes on particle size distribution of iron-cerium phosphates, because particle size was in a

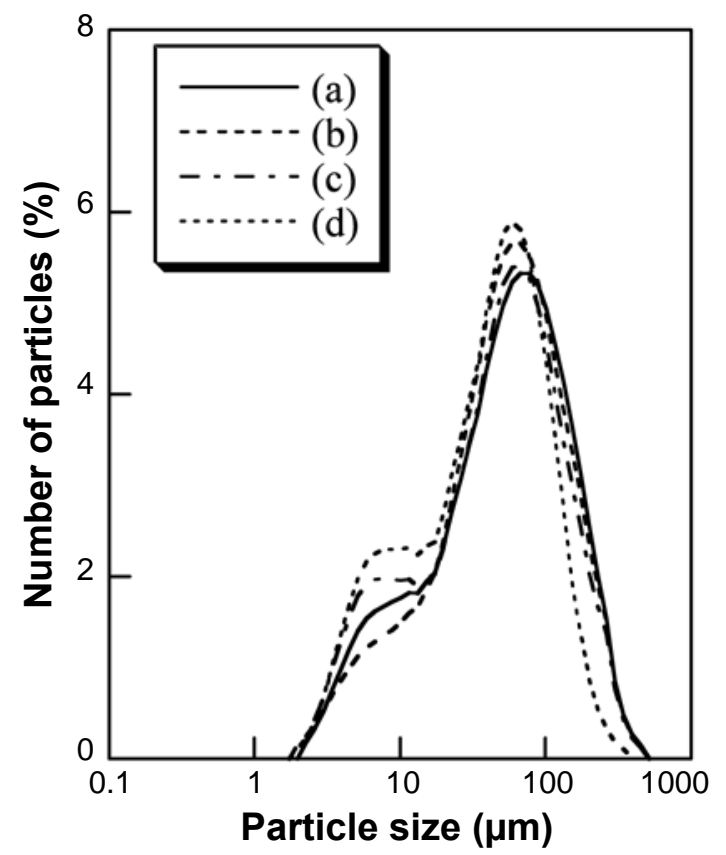

Figure 3: Particle size distributions of samples dried at $60{ }^{\circ} \mathrm{C}$, (a) $\mathrm{Fe} / \mathrm{Ce}=10 / 0, \mathrm{P} / \mathrm{sur}=10 / 0$, (b) $\mathrm{Fe} / \mathrm{Ce}=8 / 2, \mathrm{P} /$ sur $=10 / 0$, (c) $\mathrm{Fe} /$ $\mathrm{Ce}=8 / 2, \mathrm{P} /$ sur $=10 / 1$, and (d) $\mathrm{Fe} / \mathrm{Ce}=8 / 2, \mathrm{P} /$ sur=10/2.

[Figura 3: Distribuições de tamanho de partícula das amostras secas a $60{ }^{\circ} \mathrm{C}$, (a) $\mathrm{Fe} / \mathrm{Ce}=10 / 0, \mathrm{P} / \mathrm{sur}=10 / 0$, (b) $\mathrm{Fe} / \mathrm{Ce}=8 / 2$, P/ sur $=10 / 0$, (c) $\mathrm{Fe} / \mathrm{Ce}=8 / 2, \quad \mathrm{P} / \mathrm{sur}=10 / 1$, e (d) $\mathrm{Fe} / \mathrm{Ce}=8 / 2, \quad P /$ sur $=10 / 2$.] logarithm. Sample prepared without surfactant had larger particles than $100 \mu \mathrm{m}$ in size by heating at $600{ }^{\circ} \mathrm{C}$.

\section{Catalytic properties of iron-cerium phosphates}

Fig. 4 shows the catalytic activity of samples prepared in $\mathrm{Fe} / \mathrm{Ce}=10 / 0$ and $8 / 2$ from the adsorption at $415 \mathrm{~nm}$. The residual ratio in absorbance was calculated on the basis of that without catalyst. The low residual ratio means high catalytic activity of iron-cerium phosphates. Sulfuric acid, as one of common acidic catalysts, had about $30 \%$ of the residual ratio in this reaction. Some iron - cerium phosphates indicated higher catalytic activity than that of sulfuric acid. Samples prepared in $\mathrm{Fe} / \mathrm{Ce}=8 / 2$ had higher catalytic activity than that in $\mathrm{Fe} / \mathrm{Ce}=10 / 0$. In previous work [17], iron phosphates heated at 60 and $600{ }^{\circ} \mathrm{C}$ indicated low catalytic activity. Because samples heated at $60{ }^{\circ} \mathrm{C}$ had large particles, the amount of acidic sites on surface of particles was small. From the results of samples heated at $600{ }^{\circ} \mathrm{C}$, the crystalline iron phosphate was considered to have little catalytic activity. In this work, samples heated at 60 and $600{ }^{\circ} \mathrm{C}$ indicated low catalytic activity, considered in relation to that of iron-cerium phosphates as a whole. These results had same tendency with previous work. The influence of surfactant was not clear on the catalytic activity of iron-cerium phosphates.

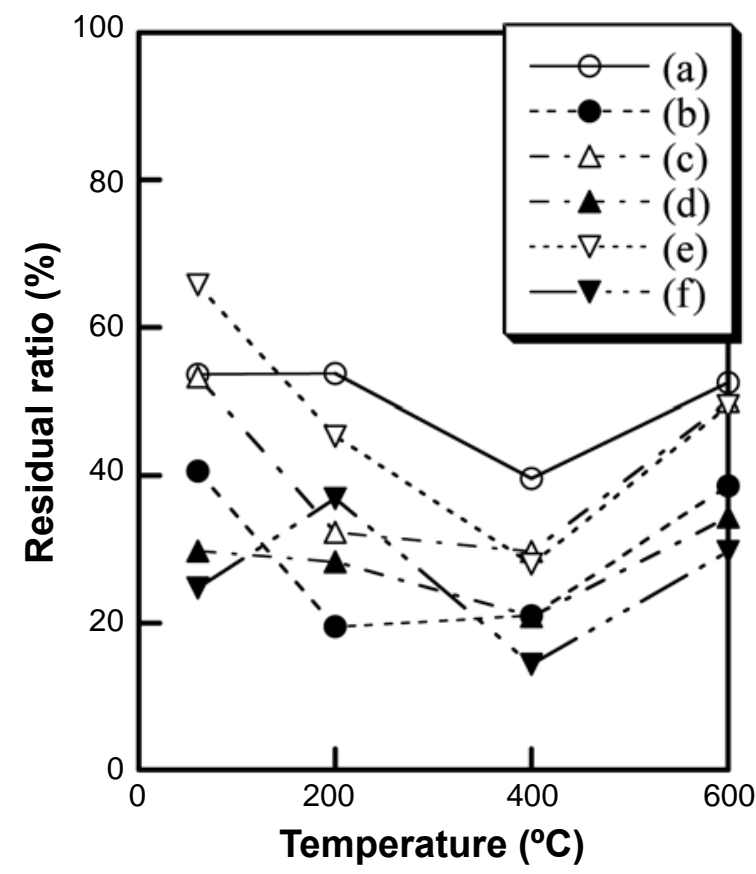

Figure 4: Catalytic activity of samples prepared in various conditions, (a) $\mathrm{Fe} / \mathrm{Ce}=10 / 0, \mathrm{P} /$ sur=10/0, (b) $\mathrm{Fe} / \mathrm{Ce}=8 / 2, \mathrm{P} /$ sur=10/0, (c) $\mathrm{Fe} / \mathrm{Ce}=10 / 0, \mathrm{P} / \mathrm{sur}=10 / 1$, (d) $\mathrm{Fe} / \mathrm{Ce}=8 / 2, \mathrm{P} /$ sur $=10 / 1$, (e) $\mathrm{Fe} /$ $\mathrm{Ce}=10 / 0, \mathrm{P} /$ sur $=10 / 2$, and (f) $\mathrm{Fe} / \mathrm{Ce}=8 / 2, \mathrm{P} /$ sur $=10 / 2$.

[Figura 4: Atividade catalitica das amostras preparadas em varias condições, (a) $\mathrm{Fe} / \mathrm{Ce}=10 / 0, \mathrm{P} /$ sur $=10 / 0$, (b) $\mathrm{Fe} / \mathrm{Ce}=8 / 2$, $\mathrm{P} / \mathrm{sur}=10 / 0$, (c) $\mathrm{Fe} / \mathrm{Ce}=10 / 0, \quad \mathrm{P} / \mathrm{sur}=10 / 1$, (d) $\mathrm{Fe} / \mathrm{Ce}=8 / 2, \quad \mathrm{P} /$ sur $=10 / 1$, (e) $\mathrm{Fe} / \mathrm{Ce}=10 / 0, \quad \mathrm{P} / \mathrm{sur}=10 / 2$, e (f) $\mathrm{Fe} / \mathrm{Ce}=8 / 2, \quad \mathrm{P} /$ sur $=10 / 2$.] 


\section{CONCLUSIONS}

Iron-cerium phosphates were prepared from iron nitrate, ammonium cerium nitrate, and phosphoric acid with a surfactant, pentaethylene glycol mono dodecyl ether. The obtained phosphates were yellow powder in color, therefore the iron condition in precipitate is mainly trivalent state. All samples had high hydrogen ratio in spite of the changes of the cerium and surfactant ratios. The peaks of $\mathrm{FePO}_{4}$ were observed in XRD patterns of samples prepared in $\mathrm{Fe} /$ $\mathrm{Ce}=10 / 0$ and then heated at $600^{\circ} \mathrm{C}$. Other samples were near amorphous states in XRD patterns. The particle size of ironcerium phosphates was from 2 to $500 \mu \mathrm{m}$. Samples prepared in $\mathrm{Fe} / \mathrm{Ce}=8 / 2$ indicated higher catalytic activity than that in $\mathrm{Fe} / \mathrm{Ce}=10 / 0$ for the decomposition of the complex from formaldehyde, ammonium acetate, and acetylacetone.

\section{REFERENCES}

[1] H. Onoda, H. Nariai, A. Moriwaki, H. Maki, I. Motooka, J. Mater. Chem. 12, 6 (2002) 1754.

[2] H. Onoda, T. Ohta, J. Tamaki, K. Kojima, Appl. Catal. A 288, 1-2 (2005) 98.

[3] H. Onoda, K. Yokouchi, K. Kojima, H. Nariai, Mater. Sci. Eng. B 116, 2 (2005) 189.

[4] W. J. Tang, PhD Thesis, University Putra, Malaysia
(2008).

[5] C. Li, H. Kawada, X. Sun, Hengyong Xu, Y. Yoneyama, N. Tsubaki, Chem. Cat. Chem. 3, 4 (2011) 684.

[6] X. Wang, Y. Wang, Q. Tang, Q. Guo, Q. Zhang, H. Wan, J. Catal. 217, 2 (2003) 457.

[7] F. Yaripour, F. Baghaei, I. Schmidt, J. Perregaard, Catal. Comm. 6, 8 (2005) 542.

[8] N. Li, G. A. Tompsett, G. W. Huber, Chem. Sus. Chem. 3, 10 (2010) 1154.

[9] D. K. Zhong, M. Cornuz, K. Sivula, M. Grätzel, D. R. Gamelin, Ener. Environ. Sci. 4 (2011) 1759.

[10] G. Guan, K. Kusakabe, S. Yamasaki, Fuel Proc. Tech. 90, 4 (2009) 520.

[11] H. Onoda, K. Asai, A. Takenaka, J. Ceram. Proc. Res. 12, 4 (2011) 439.

[12] H. Onoda, K. Taniguchi, I. Tanaka, Microp. Mesop. Mater. 109, 1-3 (2008) 193.

[13] K. Shinoda, H. Kunieda, T. Arai, H. Saijo, J. Phys. Chem. 88 (1984) 5126.

[14] H. Onoda, T. Sakumura, Mater. Sci. Appl. 2, 11 (2011) 1578.

[15] H. Onoda, H. Matsui, I. Tanaka, Mater. Sci. Eng. B 141, 1-2 (2007) 28.

[16] H. Onoda, K. Tange, I. Tanaka, J. Mater. Sci. 43, 16 (2008) 5483.

[17] H. Onoda, T. Sakumura, Phos. Res. Bull. 27 (2012) 28. (Rec. 20/06/2012, Ac. 10/11/2012) 